\title{
BROTAÇÃO DE ORA-PRO-NÓBIS EM SUBSTRATO ALTERNATIVO DE CASCA DE ARROZ CARBONIZADA
}

\author{
J. A. CAMPOS ${ }^{1 *}$, N. J. F. OLIVEIRA ${ }^{2}$, J. S. V. CHAMBA ${ }^{3}$, F. COLEN $^{2}$, C. A. $\operatorname{COSTA}^{2}$, A. S. S. FILHO ${ }^{2}$ \\ ${ }^{1}$ Universidade Federal de Viçosa - UFV, ${ }^{2}$ Universidade Federal de Minas Gerais - UFMG, \\ ${ }^{3}$ Universidade Federal Rural do Rio de Janeiro - UFRRJ \\ jasminealvescampos@gmail.com ${ }^{*}$
}

Submetido 16/10/2017 - Aceito 20/11/2017

DOI: $10.15628 /$ holos.2017.6424

\section{RESUMO}

Ora-pro-nóbis, conhecido popularmente como "carne de pobre", é utilizado pelo potencial alimentício e medicinal. A propagação por estacas caulinares constitui a forma de multiplicação usualmente empregada. No entanto, existem poucos estudos sobre o cultivo desse vegetal. Dessa forma, o objetivo com esse trabalho foi avaliar o perfil de brotações estacas caulinares de orapro-nóbis em substrato de casca de arroz carbonizada. 0 estudo foi desenvolvido no Instituto de Ciências Agrárias da Universidade Federal de Minas Gerais (ICA/UFMG). 0 experimento foi instalado em Delineamento Inteiramente Casualizado (DIC), contendo três tratamentos, estacas do tipo apical, mediana e basal, com respectivamente 30,60 e 30 repetições. O substrato constitui-se de casca de arroz carbonizada e areia lavada (1:1). Inicialmente, determinou-se o número de gemas e o diâmetro por tipo estaca e porção, avaliado pelo programa SAEG. O número, comprimento e a taxa de sobrevivência foram analisados pelo erro padrão em programa Microsoft Excel $^{\circ}$ 2013. As estacas do tipo apical apresentaram mais gemas. As primeiras emissões de brotos foram observadas após sete dias do plantio para as estacas medianas e basais. Verificou-se menor taxa de sobrevivência e menor número de brotações em estacas apicais. Quanto ao tipo, as estacas basais destacaram no comprimento nas posições medianas e basais. Estacas basais e medianas apresentaram melhores resultados de número de brotações nas porções. Conclui-se que estacas medianas e basais de ramos de $P$. aculeata foram mais viáveis e apresentaram mais brotações aos 37 dias. Pesquisas como esta constitui um dado novo, sendo necessários futuros estudos sobre o perfil de enraizamento da espécie.

PALAVRAS-CHAVE: Lobrobó, Estaquia, Pirólise, Oryza sativa.

\section{SHOOT GROWTH OF ORA-PRO-NÓBIS IN ALTERNATIVE SUBSTRATE OF CARBONIZED RICE HUSK}

\section{ABSTRACT}

Ora-pro-nóbis, popularly known as "poor meat", is used by the food and medicinal potential. The propagation by stem cuttings is the form of multiplication usually employed, however, there are few studies on the cultivation of this plant. Thus, this work aimed to evaluate the profile of buds of ora-pro-nóbis in substrate of carbonized rice husk. The study was developed at the Institute of Agrarian Sciences of the Federal University of Minas Gerais (ICA / UFMG). The experiment was installed in a completely randomized design (DIC), containing three treatments: apical, medial and basal cuttings, with 30,60 and 30 repetitions, respectively. The substrate consists of charred rice husk and washed sand (1: 1). Initially, the number of buds and the diameter by cutting type and portion, evaluated
\end{abstract}

by the SAEG program, were determined. The number length and survival rate were analyzed by the standard error in Microsoft Excel ${ }^{\circledR} 2013$ program. Apical type cuttings presented more buds. The first shoot emissions were observed after seven days of planting for the medium and basal cuttings. There was a lower survival rate and fewer shoots on apical cuttings. As for the portion of the cutting, basal cuttings stood out in length in the median and basal positions. The basal and median stakes showed better results in the number of shoots in the portions. It was concluded that medium and basal cuttings of $P$. aculeata branches were more viable and showed more shoots at 37 days. Researches such as this constitute a new data, and future studies on the rooting profile of the species are necessary.

KEYWORDS: Barbados gooseberry, Cutting, Pyrolysis, Oryza sativa. 


\section{INTRODUÇÃO}

O ora-pro-nóbis (Pereskia aculeata) - Cactaceae, também conhecido como "carne de pobre" por conter alto teor protéico, aproximadamente $25 \%$, destaca-se em relação a outras folhosas como o espinafre, que possui $2,2 \%$ de proteínas (Silva Júnior et al., 2010). Esta característica relaciona-se aos usos alimentícios e medicinais. Trata-se de uma trepadeira arbustiva, perene, considerada como hortaliça não convencional. Possui como principal forma de propagação a vegetativa, por estacas caulinares (BRASII, 2010a).

A alimentação é considerada um direito fundamental; o poder público deve realizar ações para garantir a segurança alimentar e nutricional da população (Brasil, 2006). Assim, entre os motivos que determinaram a escolha deste tema foi contribuir com conhecimentos técnicos e científicos para o crescimento e produção de ora-pro-nóbis, estes capazes de ajudar nas ações de combate à fome e desnutrição.

Apesar da importância alimentícia, medicinal e cultural, ainda existem poucos estudos a respeito do processo de cultivo desse vegetal. Um exemplo pode ser a utilização da casca de arroz carbonizada (CAC) como substrato para essa cultura. A valorização das pesquisas referentes à ampliação dos usos e cultivo de $P$. aculeata pode possibilitar o aumento da produtividade e envolver benefícios sociais e econômicos.

No contexto social, novas pesquisas são relevantes para produtores rurais obterem mais informações sobre o cultivo de determinadas espécies, em consequência da escassez de estudos agronômicos. Fortalecer esse aspecto é fundamental para a difusão dessa hortaliça não convencional para além do cultivo doméstico, ampliando a escala comercial para o uso alimentar e medicinal de ora-pro-nóbis, gerando renda na cadeia dessa hortaliça e preservação da cultura alimentícia, especialmente em Minas Gerais, Brasil.

Portanto, objetivou-se com esse trabalho avaliar o tipo de estaca caulinar e a porção da estaca de $P$. aculeata que apresenta melhor perfil de brotações em substrato alternativo de casca de arroz carbonizada.

\section{REVISÃO BIBLIOGRÁFICA}

\subsection{Pereskia aculeata: hortaliça não convencional}

De acordo com Brasil (2010a), ora-pro-nóbis, como popularmente é conhecida, significa rogai por nós em latim. Supõe-se que esse nome tenha surgido porque as pessoas colhiam a planta no quintal de um padre, enquanto este rezava o "rogai por nós". O termo aculeata, proveniente do nome científico $P$. aculeata significa espinho ou agulha (Accorsi \& Dosouto, 2006). Outros nomes populares são azedinha, espinho-preto, Surucucu, cipó-santo, lobolôbô, espinho de Santo Antônio, carne de pobre, groselha-da-américa, jumbeba, cereja-de-barbados, lobodó e lobrobó (Rocha et al., 2008; Silva Júnior et al., 2010; Taylor et al., 2012).

O ora-pro-nobis compreende o gênero Pereskia e as espécies $P$. aculeata e $P$. grandifolia, (Almeida \& Correa, 2012). O vegetal pertence à família das Cactaceae, sendo um dos poucos que 
apresenta folhas desenvolvidas e não totalmente modificadas em acúleos (BRASIL, 2010a). Plantas desse gênero ocorrem em regiões áridas ou locais levemente áridos, possuem caules finos, sublenhosos ou lenhosos, dos quais partem folhas largas com alguns espinhos na base, apresentam flores terminais solitárias ou em cimeiras curtas (Duarte \& Hayashi, 2005).

Pereskia aculeata é planta perene e com características de trepadeira, apresentando folhas suculentas e lanceoladas, as flores são pequenas e brancas, os frutos são amarelos do tipo baga e no caule existem acúleos, sendo que nos ramos mais antigos crescem aglomerados (Accorsi \& Dosouto, 2006).

De acordo com Silva Júnior et al., (2010) essa planta é originária da América tropical. Taylor et al., (2012) classificam P. aculeata como planta nativa não endêmica no Brasil, possuindo distribuição geográfica nos estados brasileiros de Alagoas, Bahia, Ceará, Maranhão, Pernambuco, Sergipe, Goiás, Espírito Santo, Minas Gerais, Rio de Janeiro, São Paulo, Paraná, Rio Grande do Sul e Santa Catarina. Na ausência de controle biológico, $P$. aculeata pode ser considerada planta daninha na África do Sul, como descrito por Moran \& Zimmermann (1991).

As hortaliças não convencionais não estão presentes no ciclo produtivo tradicional e limitam-se a algumas localidades, nas quais influenciam diretamente a alimentação e cultura local (BRASIL, 2010a). Dentre essas, encontra-se $P$. aculeata em Minas Gerais, em especial no município de Sabará. Anualmente, nessa cidade é realizado o Festival do Ora-pro-nóbis, no qual, por meio de diversas receitas é demostrado como essa hortaliça está arraigada na alimentação e na cultura da população (Sabará, 2017).

Embora com alta quantidade de nutrientes como em fibras, carboidratos, sais minerais, vitaminas e água, importantes para o bom funcionamento do organismo, as hortaliças não convencionais muitas vezes são pouco utilizadas pela população (BRASIL, 2010b). Isso ocorre por causa do desconhecimento das características nutricionais ou mesmo do modo de preparo, limitando o consumo (Rocha et al., 2008). Assim, a inclusão dessas alternativas na alimentação humana, como o ora-pro-nóbis, pode ser fonte de nutrientes acessível e de baixo custo. A pesquisa com vegetais não convencionais pode contribuir para amenizar carências nutricionais, principalmente da população desprovida de outras fontes de renda e alimentos, atuando no combate a fome (Pinto, Vilas Boas \& Carvalho, 1999; Rocha et al., 2008; Souza et al., 2009). Além disso, Souza et al., (2009) relataram que a produção de $P$. aculeata é alternativa para o aumento da renda dos pequenos agricultores, por diversificar a produção agrícola.

\subsection{Propriedades e usos do ora-pro-nóbis}

Essa planta é utilizada popularmente pelo seu potencial alimentício e medicinal. E o fato de apresentar elevados teores de proteína, lisina e de mucilagem, tem despertado a atenção da indústria alimentícia e farmacológica (Souza et al., 2009). Além disso, Sartor et al., (2010) e Ramalho \& Mannigel (2012) citaram P. aculeata pela importância ornamental, por ser trepadeira arbustiva. Brasil (2010a) a destaca como cerca viva e a indica para produção de mel, com a floração predominante de janeiro a abril.

$\mathrm{O}$ alto teor de nutrientes e a ausência de toxicidade das folhas dessa espécie a torna importante fonte de alimento para seres humanos e animais (Duarte \& Hayashi, 2005; Mercê et 
al., 2001; Rosa \& Souza, 2003; Souza et al., 2009). De acordo com Rocha et al., (2008), essa hortaliça não convencional apresenta folhas suculentas e comestíveis, podendo ser usada na alimentação de várias formas, como farinhas, saladas, refogados, tortas e adicionada às massas, como macarrão. Os frutos também são comestíveis (Ramalho \& Mannigel, 2012).

Segundo Mercê et al., (2001), as folhas de P. Aculeata apresentam 25,5 \% de proteína, alto teor se comparado a couve, com 1,6 \% e ao feijão, com 18 a $20 \%$. Rocha et al., (2008) ao pesquisarem a adição de ora-pro-nóbis ao macarrão, determinaram a composição química de $P$. aculeata e encontraram 22,93 \% de proteína, além de $12,64 \%$ de fibras, 3,64 \% de lipídeos, 36,18 $\%$ de carboidratos e 269,16 Kcal em $100 \mathrm{~g}$. Além do aspecto proteico, as indústrias alimentícias vêm incluindo o ora-pro-nóbis em complementos alimentares, por causa do alto teor do biopolímero arabinogalactano, considerado como fibra funcional (Mercê et al., 2001).

Quanto ao aspecto medicinal, as folhas são empregadas topicamente como emoliente na medicina popular, em razão do alto conteúdo mucilaginoso (Farago et al., 2004); na recuperação de processos inflamatórios e queimaduras (Sarto et al., 2010). Os frutos são utilizados como expectorante e antissifilítico (Duarte \& Hayashi, 2005; Rosa \& Souza, 2003; Sartor et al., 2010). Silva Júnior et al., (2010) relataram que as folhas possuem atividades antitumorais, antiparasitárias contra Tripanossoma cruzi, além de potenciais efeitos antidiabéticos e antianêmicos.

\subsection{Propagação vegetativa de $P$. aculeata}

Para Kämpf (2005), a estaquia consiste em uma prática muito utilizada, visto a facilidade de muitas plantas produzirem raízes adventícias. De acordo com o mesmo autor, as estacas podem ser classificadas de acordo com o material de origem, se provenientes de caule, folha ou raízes; conforme a posição na planta, se apicais ou intermediárias; e segundo a consistência do tecido, em lenhosa, semilenhosa e intermediária.

Brasil (2010a) orienta que as estacas de $P$. aculeata devem ser obtidas a partir da região intermediária do caule, entre a parte mais tenra e as mais lenhosas da haste, possuindo aproximadamente $20 \mathrm{~cm}$ de comprimento. Três tipos de estacas de ora-pro-nóbis selecionadas conforme a posição no ramo como apicais, medianas e basais e em dois tipos de substratos, areia e material comercial tratadas com extrato aquoso de Kalonchoe pinnata do enraizamento demonstraram em estacas apicais menor porcentagem de sobrevivência (Sarno \& Pasin, 2013).

Tofanelli \& Resende (2011) utilizaram em experimento para determinação de sistemas de condução na produção de folhas de ora-pro-nóbis estacas com $30 \mathrm{~cm}$ de comprimento, $10 \mathrm{~mm}$ de diâmetro e desprovidas de folhas, originárias da parte mediana de ramos maduros na planta matriz. Essas contraversões devem-se à escassez de informações técnico-científicas sobre o seu cultivo e principalmente em relação a métodos de propagação do ora-pro-nóbis (Ramalho \& Mannigel, 2012; Silva, 2012; Tofanelli \& Resende, 2011).

\subsection{Substrato}

De acordo com Fachinello, Hoffmann \& Nachtigal (2005), o substrato é empregado com a finalidade de sustentar e evitar a desidratação da estaca durante o enraizamento, mantendo a 
base em ambiente escuro. Além disso, o bom substrato precisa possibilitar a retenção adequada de água, a quantidade de espaço poroso necessária para facilitar o fornecimento de oxigênio, ser de baixo custo e de fácil aquisição, além de, preferencialmente, ser inóculo a organismos saprófitos. Esse pode variar de acordo com a dificuldade de enraizamento da espécie a ser plantada. Kämpf (2005) afirma que o substrato pode ser formado por um ou diversos materiais, em mistura.

No experimento de Tofanelli \& Resende (2011) utilizou-se como substrato terra de barranco em invólucros de polietileno, com 0,25 m de comprimento e 0,15 m de diâmetro. Brasil (2010) sugere terra de subsolo e esterco curtido na proporção de 1:1.

Mazia \& Sartor (2012), recomendam para o cultivo de $P$. aculeata solos argilosos ou ricos em matéria orgânica para obtenção de folhas com alto teor de proteína; em terrenos arenosos identificou-se quantidade menor desse nutriente na parte aérea. Ora-pro-nóbis é considerado vegetal rústico e persistente, que se desenvolve em diferentes tipos de solos, não sendo exigente em fertilidade e muito tolerante a seca (Brasil, 2010a; Guimarães et al., 2009; Sartor et al., 2010; Tofanelli \& Resende, 2011). No entanto, para o crescimento rápido é necessário manter bom nível de matéria orgânica no solo, podendo as adubações ser feitas a cada dois meses (Brasil, 2010a).

\subsection{Produção em substrato alternativo: casca de arroz carbonizada e areia}

O substrato obtido da carbonização da casca de arroz para o enraizamento de plantas pode ser utilizado de forma pura ou em misturas, possui baixa densidade e baixa retenção de água, porém superior que a areia. Apresenta drenagem rápida e eficiente, exigindo regas frequentes e devido aos macroporos possuirem boa aeração (Kämpf, 2005).

A casca de arroz carbonizada (CAC) é considerada substrato estéril devido ao processo de carbonização, sendo utilizada para germinação de sementes e enraizamento de estacas (Souza, 1993 apud Chu; Duarte \& Tremacoldi, 2007). O uso da CAC possibilita benefícios ambientais, por ser resíduo da indústria de arroz, e econômicos, pois reduz o custo de matéria prima na produção de mudas (Souza, Carniel \& Fochesato, 2006). Segundo Fermino (2003), o solo pode ser um dos principais meios de transmissão de fitopatógenos, necessitando conhecer novos substitutos para esse substrato.

A areia é um material quimicamente inerte de alta densidade, utilizado para o enraizamento de estacas ou para aumentar a densidade de substratos, possui também boa aeração, drenagem e baixa retenção de água (Kämpf, 2005). As vantagens dessa como substrato são o baixo custo, a fácil disponibilidade e a boa drenagem sob nebulização, sendo adequada para enraizamento de estacas herbáceas e semilenhosas, porém é inadequada para o uso em ambientes externos, por reter pouca água (Fachinello, Hoffmann \& Nachtigal, 2005).

\section{MATERIAL E MÉTODOS}

O presente estudo foi desenvolvido no viveiro de mudas do Instituto de Ciências Agrárias da Universidade Federal de Minas Gerais - ICA/UFMG, Campus Montes Claros. O município está 
situado na Bacia do Alto Médio São Francisco, Norte de Minas Gerais, região sudeste do país, sendo o local definido pelas coordenadas geográficas: altitude de $630 \mathrm{~m}$ latitude de $16^{\circ} 40^{\prime} 59,10^{\prime \prime} \mathrm{S}$ e longitude de $43^{\circ} 50^{\prime} 26.50^{\prime \prime} \mathrm{W}$. O clima é denominado Aw, clima tropical com inverno seco, segundo classificação climática de Köppen (Alvares et al., 2013).

O experimento foi instalado em Delineamento Inteiramente Casualizado (DIC), contendo três tratamentos, compostos por três tipos de estacas seccionadas de acordo com a posição do ramo na planta matriz. As estacas foram denominadas como do tipo apical, mediana e basal, e possuíam comprimento de $21 \mathrm{~cm}$ cada. 0 experimento foi composto por 30 repetições para as estacas da parte apical do ramo, 30 repetições para estacas da parte basal e 60 para as estacas da parte mediana, totalizando 120 estacas.

Foram coletados ramos de planta matriz de identificação botânica de $P$. aculetata Mill e no do tombo 3807, no horto medicinal do ICA/UFMG. Dos ramos, foram retiradas todas as folhas e cortadas, em bisel, estacas com comprimento de $21 \mathrm{~cm}$.

Logo após o corte, cada estaca foi colocada em reservatório com água para evitar a desidratação, sendo agrupadas de acordo com a posição ocupada no ramo da planta de origem (apical, mediana ou basal), até o plantio. As estacas foram reservadas observando o fluxo de condução da seiva, ou seja, durante o plantio foi necessário ter o cuidado de deixar os espinhos P. aculetata direcionados para baixo.

Antes de reservar o material de propagação em água, conforme posicionamento no ramo, como mencionado anteriormente, foi aferido o diâmetro em diferentes porções da estaca, com um paquímetro digital de capacidade 0 a $150 \mathrm{~mm}$ e exatidão aproximadamente 0,02 $\mathrm{mm}$. Primeiro na porção basal de 0 a $7 \mathrm{~cm}$ da base da estaca. Segundo na porção mediana, $7,1 \mathrm{a} 14 \mathrm{~cm}$ do caule da estaca, correspondendo o meio da estaca. E de 14,1 a $21 \mathrm{~cm}$ do caule, sendo considerado o ápice da estaca. Além disso, realizou-se o levantamento do número de gemas existentes nesses três intervalos, para os três tratamentos.

O substrato para o plantio foi preparado antecipadamente, sendo composto por dois componentes, CAC e areia de granulometria média na proporção 1:1. Em um canteiro delimitado inferior e lateralmente por plástico de polietileno preto e também na lateral por madeira, foi colocada a areia e a casca de arroz carbonizada. Esse tipo de substrato é usualmente empregado para propagação caulinar no viveiro de plantas do ICA/UFMG.

Seguindo recomendação de Brasil (2010a), as estacas, no plantio, foram enterradas na proporção de $1 / 3$ do comprimento, neste caso correspondendo a $7 \mathrm{~cm}$. E o espaçamento adotado entre estacas foi de aproximadamente $10 \mathrm{~cm}$.

As mudas receberam irrigações diárias por meio de nebulizadores até atingir a capacidade de campo, uma vez que os substratos utilizados possuíam baixa retenção de água. $E$, dependendo das precipitações, a irrigação do dia foi suspensa. Segundo Fachinello, Hoffmann \& Nachtigal (2005) o sistema de nebulização mantém a umidade relativa do ar elevada o que beneficia a propagação por estaquia, juntamente com altas temperaturas aumenta a velocidade de crescimento das plantas.

Após o início das primeiras brotações, que ocorreram no sétimo dia após plantio, realizaram medições quinzenais aos 07, 22 e 37 dias após plantio. Os comprimentos das 
brotações foram mensuradas com o paquímetro digital e foram anotadas suas medidas, considerando a porção na qual o broto aparece na estaca e o tipo de estaca correspondente a posição no ramo da planta matriz. Considerando a porção basal localizada próxima ao substrato, a mediana (intermediária) e a porção apical (distal ao substrato). Além disso, foi avaliado o número de brotos por tipo de estaca viável e por porção da estaca, como também a taxa de mortalidade.

O levantamento inicial, constituído da caracterização das estacas quanto ao diâmetro e número de gemas foi avaliado estatisticamente por análise de variância (ANOVA) no programa Sistema de Análises Estatísticas e Genéticas (SAEG, 2007). A comparação das médias foi realizada pelo teste de Tukey, com nível de significância de 5,0\%. Os dados de comprimento, número de brotos e estacas viáveis foram analisados por média e erro padrão, para cada tipo de estaca e para cada porção da estaca, em programa Microsoft Excel ${ }^{\circledR}$ 2010. A barra de erro padrão da média possibilitou comparar as amostras por dispersão em torno da média, com valores superiores e inferiores.

\section{RESULTADOS E DISCUSSÃO}

\subsection{Análise do número de gemas axiais e diâmetro do caule}

Na Tabela 1 são apresentados os resultados para o número médio de gemas axiais nos três tipos de estacas do caule de ora-pro-nóbis.

Tabela 1: Número de gemas axiais para diferentes tipos e porções de estacas de $\boldsymbol{P}$. aculeata

\begin{tabular}{lccc}
\hline \multicolumn{3}{c}{ Médias do número de gemas axiais } \\
\hline Tipo de estaca & $\begin{array}{c}\text { Porção basal } \\
(0 \text { a } 7 \mathrm{~cm})\end{array}$ & $\begin{array}{c}\text { Porção mediana } \\
(7,1 \text { a } 14 \mathrm{~cm})\end{array}$ & $\begin{array}{c}\text { Porção apical } \\
(14,1 \text { a } 21 \mathrm{~cm})\end{array}$ \\
\hline Apicais $\mathrm{n}=30$ & $3,3333 \mathrm{~A}$ & $3,5667 \mathrm{~A}$ & $3,5333 \mathrm{~A}$ \\
Medianas $\mathrm{n}=60$ & $2,8833 \mathrm{~B}$ & $3,0167 \mathrm{~B}$ & $3,0000 \mathrm{~B}$ \\
Basais $\mathrm{n}=30$ & $2,5667 \mathrm{~B}$ & $2,7667 \mathrm{~B}$ & $2,6333 \mathrm{~B}$ \\
\hline
\end{tabular}

${ }^{A}$ Letras maiúsculas iguais nas colunas são semelhantes no teste Tukey $(p \leq 0,05)$.

Fonte: Autoria própria, 2017.

Os resultados demonstraram maior número médio de gemas axiais $(p<0,05)$ nas estacas provenientes da região apical da planta matriz, independentemente da porção da estaca considerada. Entretanto, entre as partes mediana e basal, as médias foram similares (Tabela 1).

De acordo com Raven, Evert \& Eichhorn (2007), os meristemas apicais localizam-se na porção apical dos caules e estão relacionados ao crescimento em comprimento da planta. Esse crescimento origina sucessões de unidades repetidas denominadas fitômeros, compostos por nó, folha, entrenó e gema axilar.

Assim, ao distanciar do meristema apical, os entrenós aumentam de tamanho e consequentemente o número de gemas apresenta-se menor (Raven; Evert \& Eichhorn, 2007). 
Então, estacas apicais devem possuir número maior de nós e entrenós, enquanto as estacas basais devem possuir menor número de nós e entrenós.

Assim espera-se que as estacas apicais apresentem maior número de brotos que as estacas basais. No entanto, há também a ação do controle hormonal, como as auxinas e citocininas. As auxinas são produzidas nos ápices caulinares e as citocininas em ápices radiculares, atuando conjuntamente no desenvolvimento do vegetal. Desta forma, as estacas apicais por se encontrarem mais próximas ao ápice da planta matriz, apresentam número de gemas axilares estatisticamente superior ao mesmo de estacas distais.

Conforme Tabela 2, as estacas da parte basal da planta apresentaram diâmetro superior $(p<0,05)$ em todas as porções avaliadas. Estas diferiram significativamente das estacas medianas, as quais foram maiores, se comparadas às apicais.

Tabela 2: Diâmetro do caule para diferentes tipos e porções de estacas de $\boldsymbol{P}$. aculeata

\begin{tabular}{lccc}
\hline & \multicolumn{3}{c}{ Médias do número de gemas axiais } \\
\hline Tipo de estaca & $\begin{array}{c}\text { Porção basal } \\
(0 \text { a } 7 \mathrm{~cm})\end{array}$ & $\begin{array}{c}\text { Porção mediana } \\
(7,1 \text { a } 14 \mathrm{~cm})\end{array}$ & $\begin{array}{c}\text { Porção apical } \\
(14,1 \mathrm{a} 21 \mathrm{~cm})\end{array}$ \\
\hline Apicais $\mathrm{n}=30$ & $6,6400 \mathrm{C}$ & $6,1467 \mathrm{C}$ & $5,7067 \mathrm{C}$ \\
Medianas $\mathrm{n}=60$ & $8,9100 \mathrm{~B}$ & $8,7417 \mathrm{~B}$ & $8,3950 \mathrm{~B}$ \\
Basais $\mathrm{n}=30$ & $11,2467 \mathrm{~A}$ & $10,7833 \mathrm{~A}$ & $10,2800 \mathrm{~A}$ \\
\hline
\end{tabular}

${ }^{A}$ Letras maiúsculas iguais nas colunas são semelhantes no teste Tukey $(p \leq 0,05)$.

Fonte: Autoria própria, 2017.

Segundo Raven, Evert \& Eichhorn (2007), as partes mais velhas do caule e afastadas da região apical, apresentam crescimento secundário, em espessura. Para os autores, esse é resultado de atividades dos meristemas laterais, como o câmbio vascular, o qual aumenta o número de células do xilema secundário, deslocando-se externamente, incrementando o diâmetro do caule. E os raios vasculares, são células parenquimáticas capazes de movimentar substâncias nutritivas do floema secundário para xilemas e água do xilema para o floema, possuem também a função de reserva, armazenando substâncias como amido, lipídios e proteínas.

Pode-se inferir que as estacas basais e medianas apresentaram crescimento secundário e possivelmente reservaram quantidades de substâncias superiores às apicais, apresentando, dessa forma, média de diâmetro do caule maior que as estacas apicais.

\subsection{Análise do número brotações por tipo de estaca}

As primeiras emissões de brotos foram observadas nas estacas medianas e basais aos sete dias após o plantio, enquanto para as apicais o início das brotações ocorreu entre oito e quinze dias. No ápice caulinar isso pode estar relacionado com a presença do hormônio vegetal auxina, produzido nesta região da planta, portanto, mais próximo das estacas do tipo apical. A superioridade de massa verde do caule para as estacas medianas e basais em relação as estacas 
apicais também foram relatados por Tavares et al. (2012) na propagação vegetativa da erva cidreira.

De acordo com Taiz \& Zeiger (2006), a gema apical é a principal produtora de auxina para a planta e é transportado de forma unidirecional, considerado transporte polar, da extremidade apical para a basal, implicando em diferença de gradiente longitudinal. Essas variações de gradiente interferem nos processos de desenvolvimento do vegetal, como alongamento do caule, inibição do crescimento das gemas axilares e determina a dominância apical. Desta forma, a proximidade da gema apical, nas estacas apicais, propiciaria maior formação de raízes, pela presença de auxinas produzidas no meristema apical do caule, como também favorece a menor emissão inicial de brotos. Já nas estacas medianas e basais, a menor quantidade desse fitohormônio por estarem mais distantes do centro produtor de auxina, possibilitaria o crescimento das gemas laterais, causando o comportamento de brotação mais rápida.

Outro fator importante a ser levado em consideração é que nem todas as gemas axilares identificadas nas estacas desenvolveram em ramos. Para Aguiar (2014), a maior parte dos meristemas axilares nunca serão ativados, sendo abortados ou continuam em dormência, se isso não acontecesse o emaranhado de ramos resultante seria energeticamente ineficiente para a planta.

A Figura 1, a seguir apresenta os dados do número de brotações por tipo de estacas após 37 dias de plantio. As estacas apicais apresentaram média de brotos por estaca menor que as medianas e as basais.

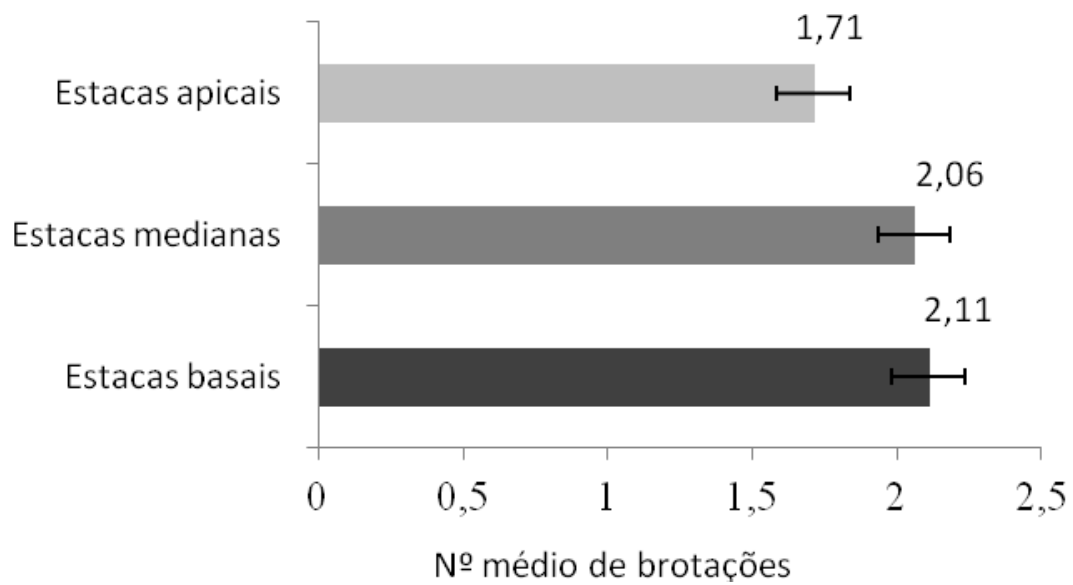

Figura 1: Número médio de brotações por tipo de estacas de $P$. aculeata aos 37 dias de plantio em substrato alternativo de CAC. Fonte: Autoria própria, 2017.

Os resultados desta pesquisa com $P$. aculeata foram semelhantes aos encontrados por Pereira et al., (2015) em diferentes tipos de estacas de pinhão manso. Conforme estes autores a brotação pode ser influenciada pela posição da estaca no ramo da planta, sendo as basais e medianas capazes de proporcionar maior número de brotos em relação às apicais.

Na propagação vegetativa de estacas da planta medicinal Hyptis pectinata, Carvalho et al., (2015) observaram maior número de brotações em estacas basais. Este resultado foi $28 \%$ superior às medianas e $75 \%$ em relação às apicais. Dessa forma, mesmo considerando diferentes 
famílias de plantas, estacas basais e medianas apresentaram melhores resultados na multiplicação vegetativa.

Higa, Fior \& Rodrigues (2012) pesquisando a propagação de $P$. aculeata por estaquia caulinar em diferentes tipos de estaca de acordo com o ramo de origem e substratos compostos por areia lavada, CAC e pó-de-coco verificaram que a multiplicação foi satisfatória independentemente dessas variáveis e da presença ou ausência de nebulização, não obtendo diferenças significativas entre tratamentos. Portanto, para a espécie em estudo, observa-se poucos estudos comparativos e conclusivos quanto o tipo de estaca adequado para propagação desta espécie.

Ao analisar o diâmetro do caule e número de brotações Tofanelli, Rodrigues \& Ono (2003) encontraram em mudas mais espessas de pessegueiros cv. Okinawa maior percentual de emissão de brotações em função da maior disponibilidade de reservas nesse tipo de estaca, possibilitando o número superior de brotações. Portanto, parece existir consenso na literatura a respeito da parte da planta indicada para a propagação vegetativa, pois Fachinello, Hoffmann \& Nachtigal (2005) recomendaram o uso de estacas medianas e basais para multiplicação de plantas frutíferas, por apresentarem maiores concentrações de substâncias de reservas.

As quantidades de carboidratos podem relacionar-se ao teor de amido passível de degradação em açúcares solúveis (Fang et al., 2007). Segundo Gibson (2005) esses componentes contribuem com o incremento do número de raízes e influenciam positivamente o desenvolvimento de órgãos e tecidos vegetais. Dessa forma, pode-se inferir que as reservas de nutrientes associaram ao metabolismo mais efetivo de brotação nas estacas medianas e basais de $P$. aculeata.

De acordo com Carvalho et al., (2015) o estudo das brotações é importante quando se trabalha com propagação de estacas. A existência de brotos e folhas permite incrementar a produção de fotoassimilados e de auxinas que são fatores primordiais para o desenvolvimento de raízes e crescimento do vegetal (Carvalho et al., 2015; Floss, 2004).

\subsection{Análise do comprimento das brotações por tipo de estaca}

Na Figura 2, a seguir, ilustra a média de comprimento das brotações de ora-pro-nóbis por tipo de estaca. Os pontos exibidos correspondem às datas das medições durante o experimento. 


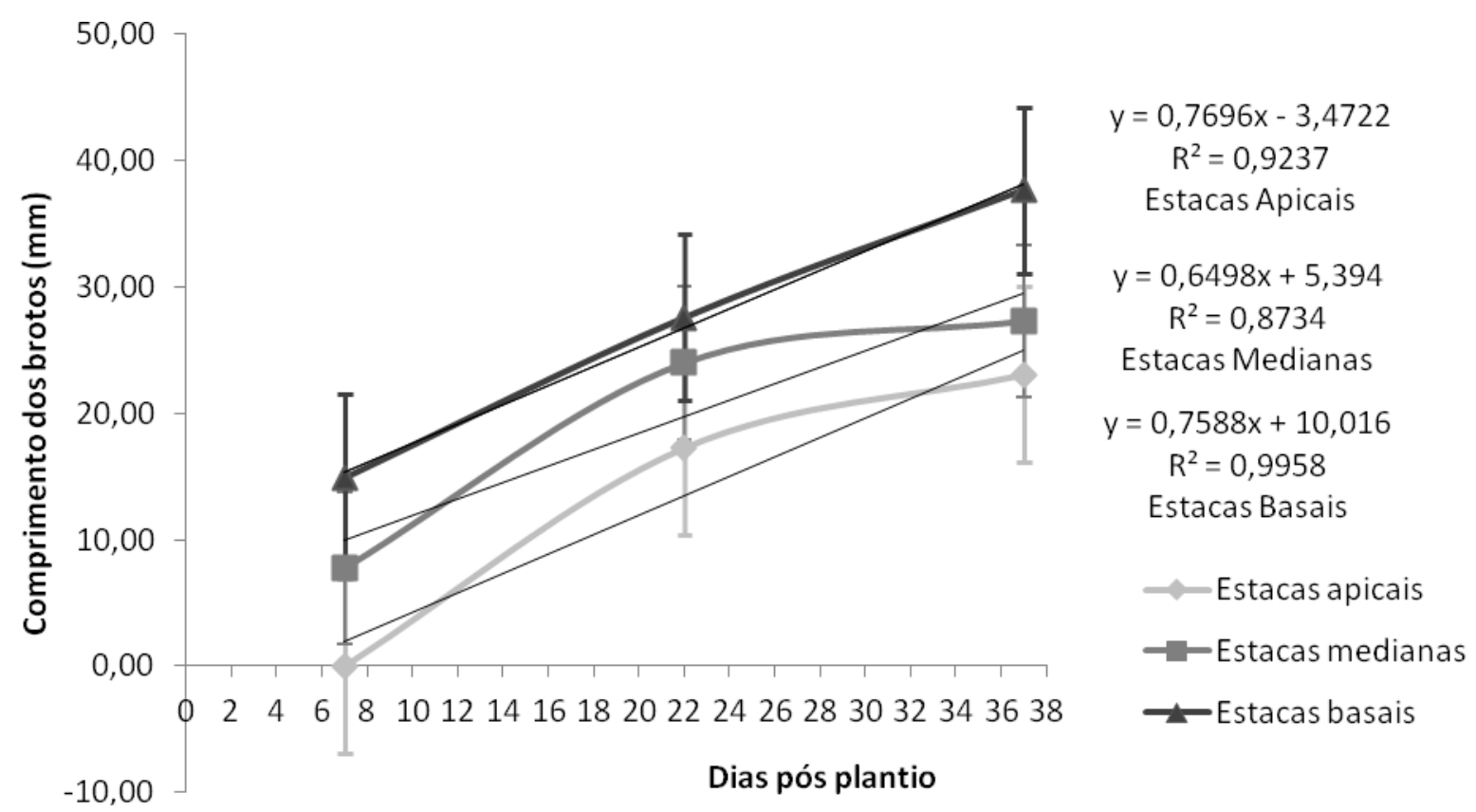

Figura 2: Média de comprimento de brotações por tipo de estacas de $P$. aculeata em diferentes tempos após o plantio em substrato alternativo de CAC. Fonte: Autoria própria, 2017.

Conforme a Figura 2, as médias de comprimento das brotações apresentaram-se crescentes, tendo respectivamente os maiores comprimentos as estacas basais, as medianas e as apicais. Resultado semelhante foi obtido por Ferreira et al., (2010), trabalhando com propagação vegetativa de maniçoba, observaram maior comprimento das brotações em estacas com maior diâmetro. Em conformidade com o discutido anteriormente, parece existir relação estreita entre a quantidade de reserva caulinar e o metabolismo das brotações, como descrito por Raven, Evert \& Eichhorn (2007) e Tofanelli, Rodruigues \& Ono (2003).

\subsection{Taxa de sobrevivência das brotações por tipo de estaca}

Na Figura 3 pode ser verificado depois de 37 dias após plantio uma elevada taxa de sobrevivência para as estacas basais e medianas. Esse resultado está em consenso com Fachinello, Hoffmann \& Nachtigal (2005), ao afirmarem que as estacas menos lignificadas são mais susceptíveis à morte por desidratação, necessitando assim de manejo mais apropriado quanto ao ambiente, porém as mais lignificadas podem ser enraizadas até mesmo no campo por serem mais resistentes a esse processo de dessecamento. 


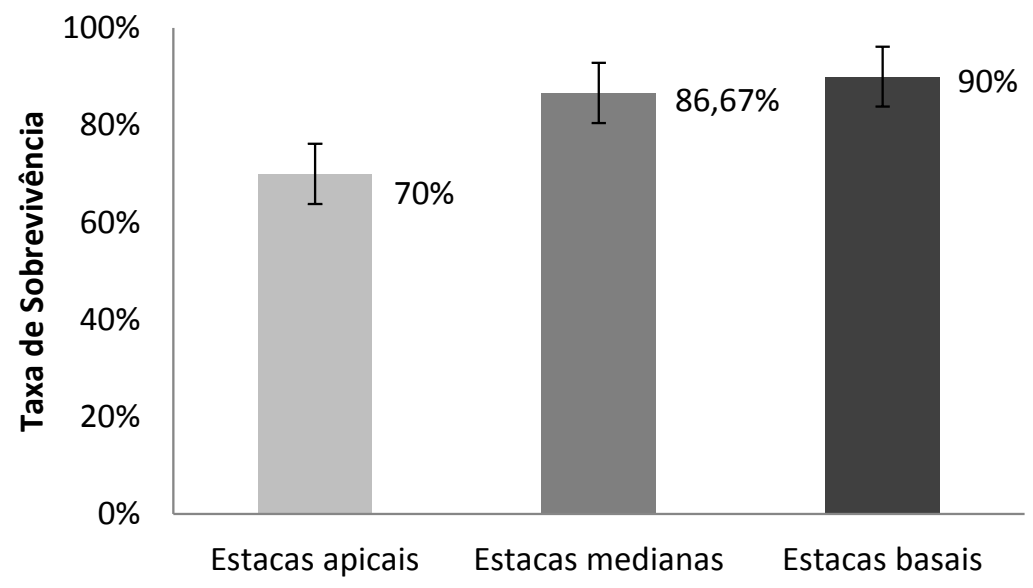

Figura 3: Taxa de sobrevivência por tipo de estacas de $P$. aculeata aos 37 dias de plantio em substrato alternativo de CAC. Fonte: Autoria própria, 2017.

Assim, verifica-se a brotação mais tardia, a maior mortalidade e o menor número médio de brotações em mudas da parte apical do ora-pro-nóbis. Isso pode ser reflexo da fisiologia de armazenamento de nutrientes do vegetal mais próxima da raiz, portanto, da parte mediana e basal. Possivelmente esse fato também justifica os maiores valores de número de brotos das partes medianas e basais da planta, conforme discutido anteriormente.

No entanto, deve-se enfatizar que a mortalidade observada, independente do tipo de estaca, também pode estar relacionada aos fungos saprófitos. Higa, Fior \& Rodrigues (2012) relatam em experimento de estaquia de ora-pro-nóbis que 6,0\% da amostra, aos 20 dias, exibia característica de fungos na parte aérea ou apodrecimento a partir da base da estaca, e aos 40 dias as estacas contaminadas por fungos morreram. Características semelhantes foram observadas neste experimento e após os 37 dias de plantio a mortalidade foi ainda mais alta, comprometendo as medições e impedindo o prosseguimento do projeto.

\subsection{Análise por porção da estaca}

Ao analisar cada porção das estacas, pode-se comparar as amostras por recurso disponibilizado pelo Microsoft Excel ${ }^{\circledast}$. Nas Figuras 4, 5 e 6 são apresentadas as médias das brotações de ora-pro-nóbis em diferentes tempos, relacionados à porção apical, mediana e basal dos diversos tipos de estacas.

Analisando a última medição, na porção apical (Figura 04) houve semelhança para o comprimento dos diferentes tipos de estacas. Portanto, não foi verificado diferenças entre os tratamentos pelo erro padrão. 
Na Figura 4 são apresentadas as médias de comprimento de brotações na porção apical de estacas de $P$.aculeata durante o período de 37 dias após o plantio em substrato alternativo de CAC.

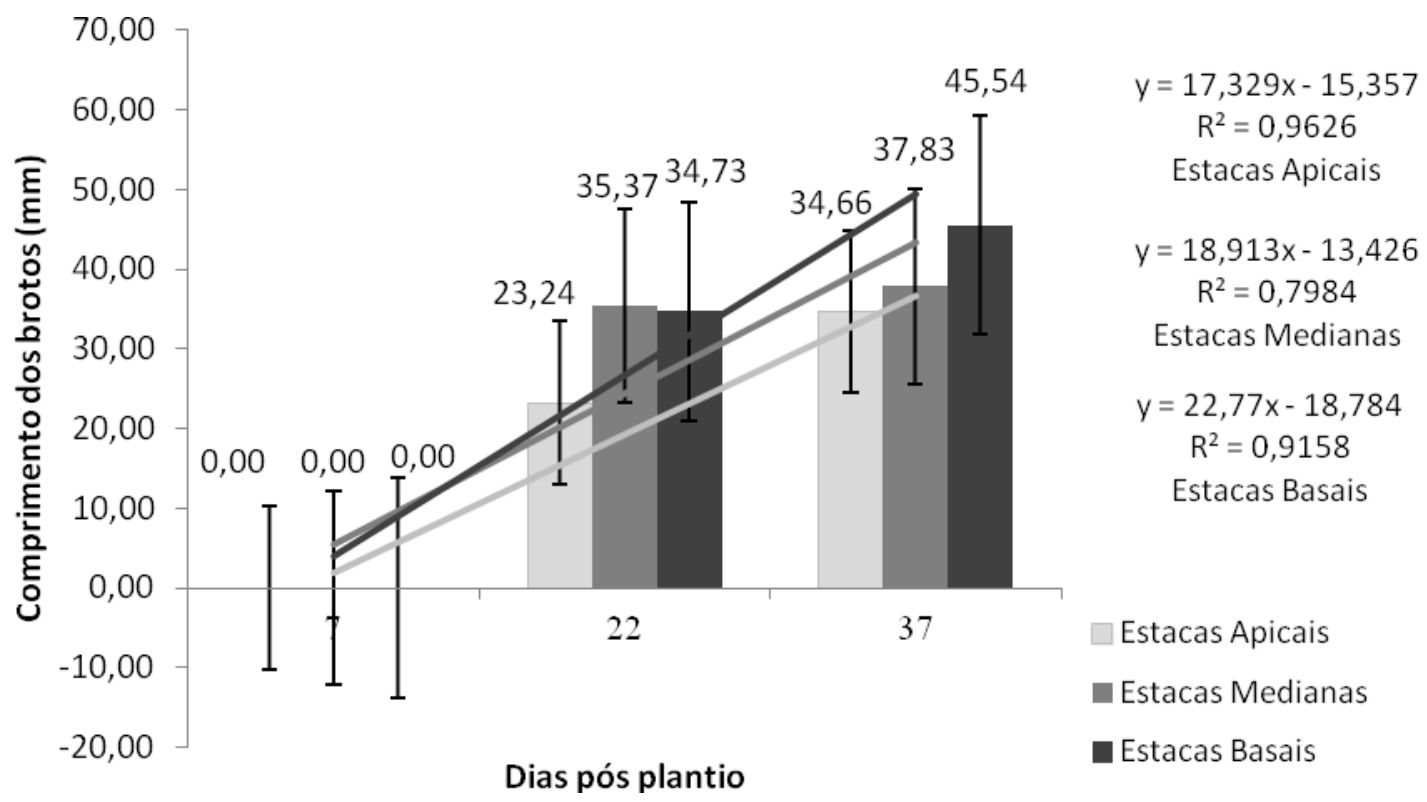

Figura 4: Média de comprimento de brotações na porção apical de estacas de $P$. aculeata durante o período de 37 dias após o plantio em substrato alternativo de CAC. Fonte: Autoria própria, 2017.

De acordo com o Figura 5, a seguir, na porção mediana as estacas basais resultaram em brotações de maior tamanho comparadas com as estacas apicais. Assim, aos 37 dias, as estacas basais foram diferentes das apicais, as primeiras obtiverem maiores valores de comprimento.

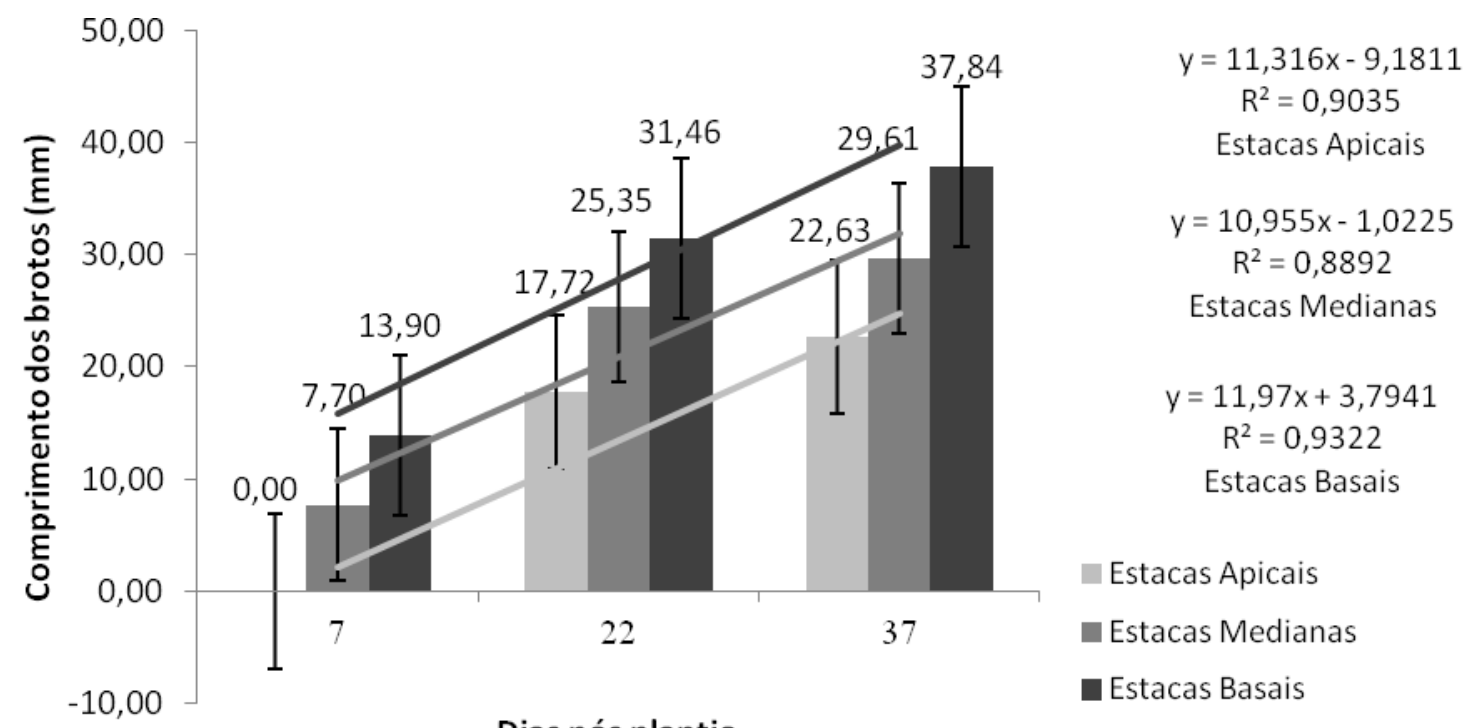

Dias pós plantio

Figura 5: Média de comprimento de brotações na porção mediana de estacas de P.aculeata durante o período de 37 dias após o plantio em substrato alternativo CAC. Fonte: Autoria própria, 2017. 
Para a porção basal (Figura 6), na última mensuração as estacas basais apresentaram comprimento superior de brotações em relação aos demais tipos de estacas. As estacas medianas e apicais foram semelhantes.

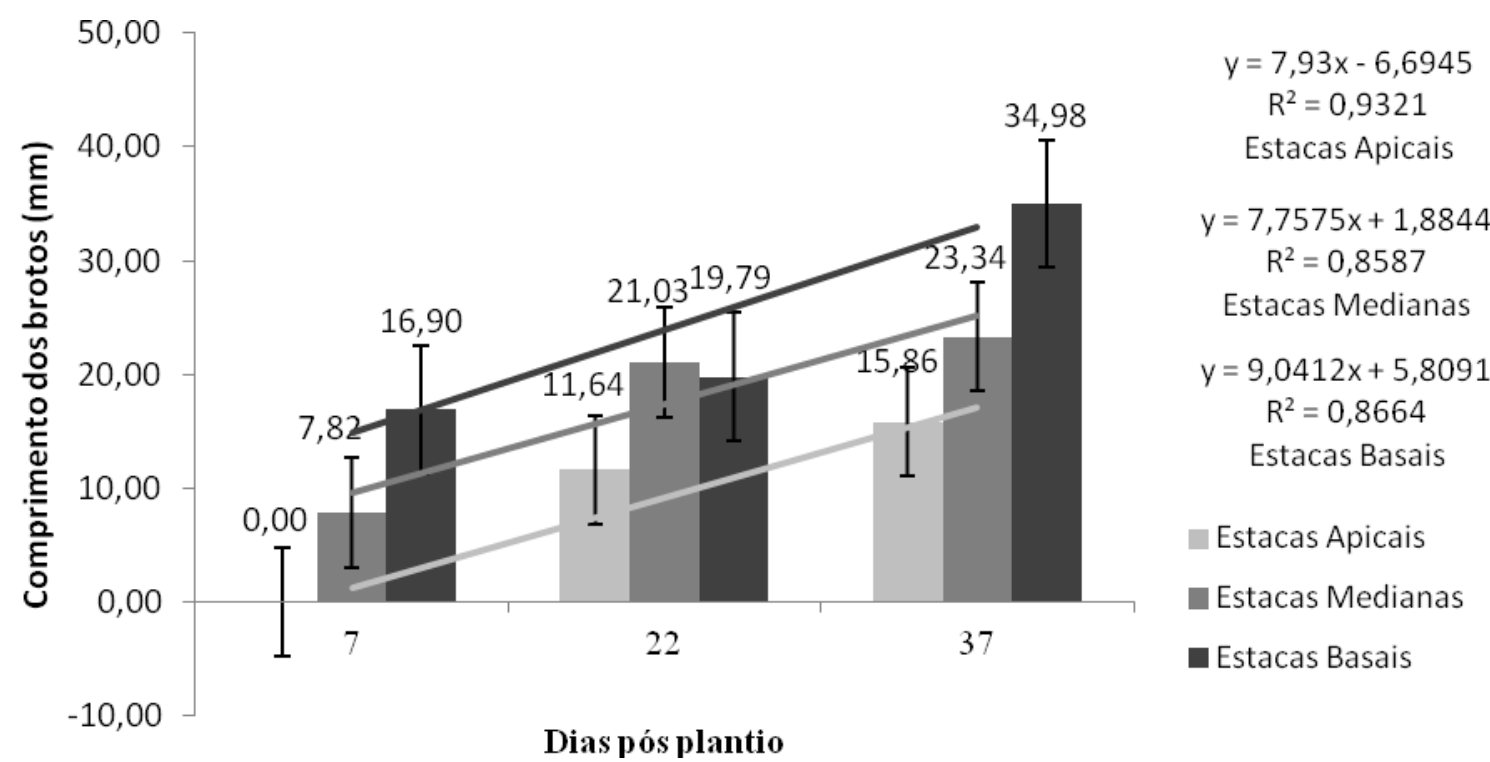

Figura 6: Média de comprimento de brotações na porção basal de estacas de $P$. aculeata durante o período de 37 dias após o plantio em substrato alternativo de CAC. Fonte: Autoria própria, 2017.

Observaram-se brotações iniciais nas porções inferiores do caule, não sendo verificada qualquer brotação na porção apical nos diferentes tipos de estacas aos sete primeiros dias após o plantio (Figura 4). Isso remete provavelmente a diferença de reservas presentes na planta, uma vez que em diferentes porções da mesma estaca há variação do diâmetro do caule (Tabela 2). Ramos maduros apresentam teores maiores de carboidratos reservados da planta matriz (Fachinello, Hoffmann \& Nachtigal, 2005), possibilitando o desenvolvimento mais rápido das brotações. Além disso, como mencionado anteriormente as estacas advindas de ramos apicais da planta matriz não apresentaram brotações na primeira medição, independentemente do tipo de porção observada, como pode ser visualizado nas três figuras seguintes.

Higa, Fior \& Rodrigues (2012) trabalhando com diferentes tipos de estacas de ora-pronóbis obtiveram massa fresca de estacas apicais correspondentes a $41 \%$ de estacas intermediárias e basais, na fase inicial do experimento. Segundo os autores, com o decorrer dos dias houve aumento da massa fresca das estacas apicais e estabilização nas intermediárias e basais, sugerindo a translocação de nutrientes de ramos para a formação de raízes. Para este trabalho, os dados são compatíveis com a fase inicial do experimento descrito por Higa, Fior \& Rodrigues (2012), que demostra menor comprimento das brotações em estacas apicais, e possivelmente a estabilização referida seria observada após os 37 dias de plantio.

De acordo ainda com as Figuras 4, 5 e 6, os diferentes tipos de estacas apresentaram desenvolvimento crescente, ilustrado pela linha de tendência. Esta possibilitou a geração da equação do gráfico e o valor $\mathrm{R}^{2}$. Em geral, as estacas basais proporcionaram comprimentos superiores às medianas e apicais. Contudo, considerando o erro padrão, nas médias pode haver 
dispersão em valores superiores e inferiores, desta forma podem existir ou não diferenças de comprimento dos brotos para os diferentes tratamentos e datas.

Analisando as Figuras 5 e 6 , verificou-se que as estacas basais proporcionaram desenvolvimento maior de brotações nas porções medianas e basais. Isso pode estar relacionado às características fisiológicas mencionadas anteriormente, pois segundo Fachinello, Hoffmann \& Nachtigal (2005) estacas basais podem apresentar mais reserva, podendo refletir em diferenças de reservas também entre as porções.

Estacas apicais podem estar sobre a ação de auxinas e esse hormônio influenciará no menor desenvolvimento da parte aérea, pois de acordo com Hartmann et al., (2002) a baixa brotação de partes vegetativas pode estar correlacionada a fatores como a concentração de fitohormônios e de carboidratos nos ramos. Para Fachinello, Hoffmann \& Nachtigal (2005), a importância dos carboidratos está relacionada à necessidade de carbono para sintetizar ácidos nucléicos e proteínas, estimulada por auxinas deslocando a necessidade de energia e carbono para formação das raízes em ramos para propagação.

Esse crescimento pode ainda estar relacionado à morfologia escandente de $P$. aculeata. Estratégias são apresentadas por trepadeiras para o apoio ou escalada, como o crescimento escandente favorecido pela presença de acúleos para evitar a queda (Aguiar, 2014; Villagra, 2008). Esse tipo de crescimento em ora-pro-nóbis foi citado por Higa, Fior \& Rodrigues (2012).

Também da família Cactaceae a Pitaya também possui hábito escandente ou trepador MARQUES (2008). Para Gonçalves \& Lorenzi (2007) as plantas que possuem caule escandente podem subir para facilitar a obtenção de luz e de fotoassimilados.

Quanto ao número médio de brotações, são apresentados nas Figuras 7, 8 e 9. Analisando-se a terceira medição na porção apical observaram-se em estacas medianas foram contadas mais brotos se comparadas às estacas basais. Porém, as apicais não foram diferentes das basais e medianas (Figura 7).

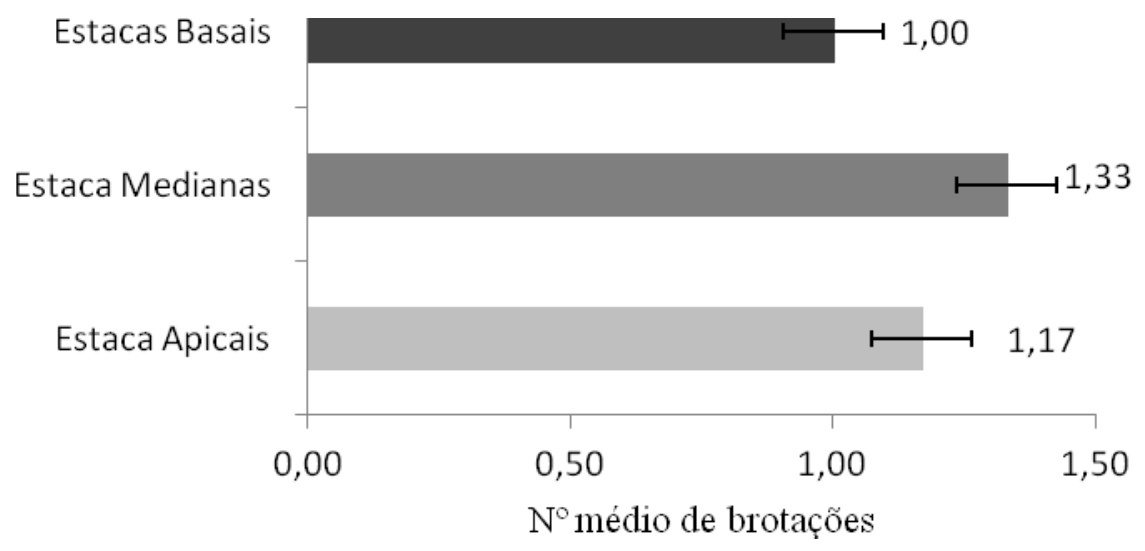

Figura 7: Número médio de brotações em porção apical de estacas de $P$. aculeata aos 37 dias de plantio em substrato alternativo de CAC. Fonte: Autoria própria, 2017. 
Conforme o Figura 8, na porção mediana as estacas basais foram diferentes dos demais tipos de estacas, obtendo maior número médio de brotações. As estacas medianas e apicais apresentaram valores próximos.

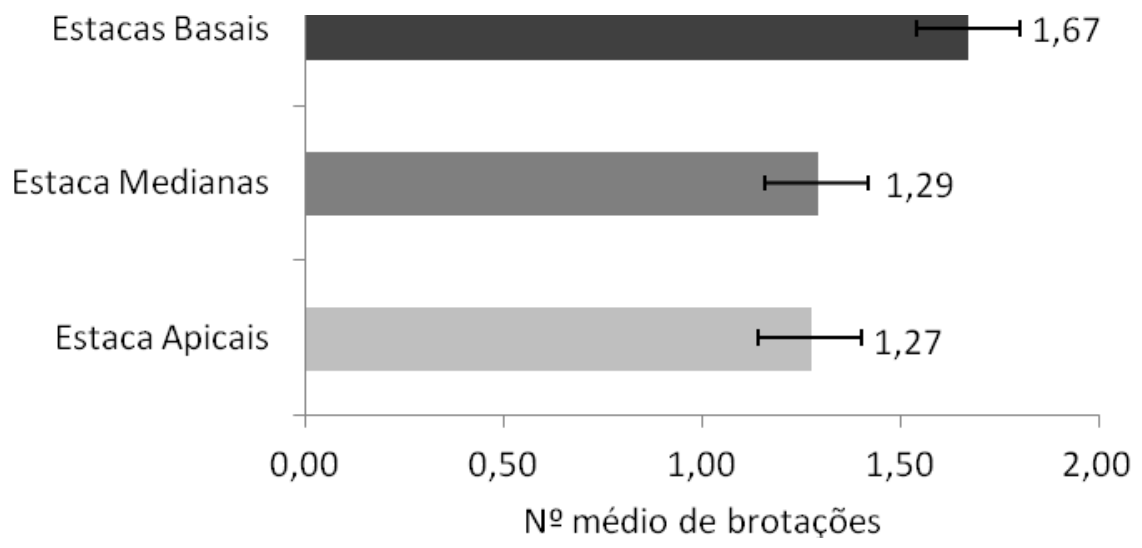

Figura 8: Número médio de brotações em porção mediana de estacas de $P$. aculeata aos 37 dias de plantio em substrato alternativo de CAC. Fonte: Autoria própria, 2017.

Na Figura 9, na porção basal, as brotações de estacas medianas foram superiores às demais. Relacionando os valores, as maiores médias de número de emissão de brotações encontraram-se na porção mediana. No entanto, por esses dados não se pode afirmar a diferença significativa entre as diferentes porções, pois não foi analisada interação entre estas.

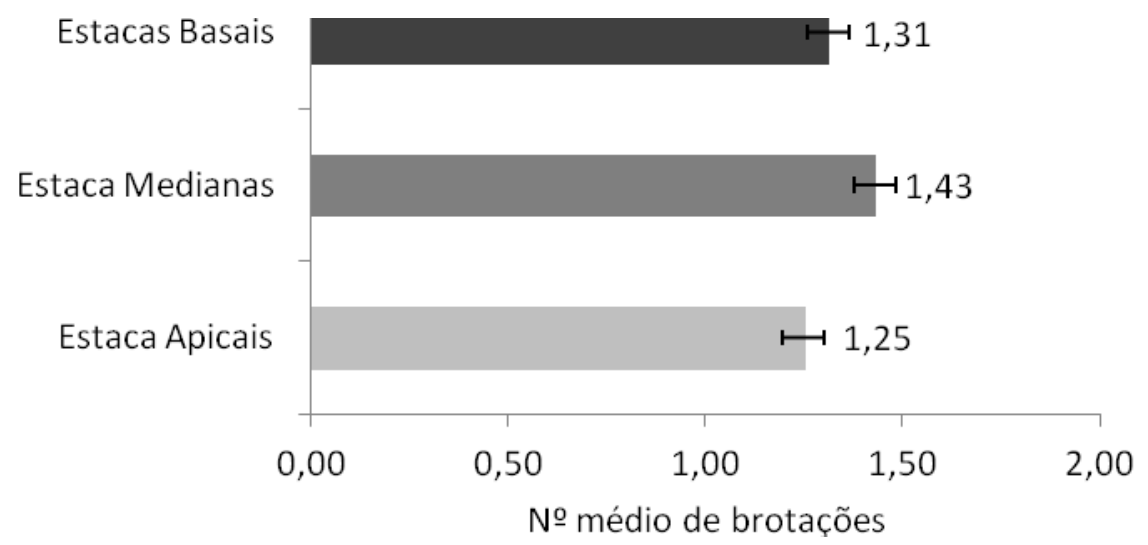

Figura 9: Número médio de brotações em porção basal de estacas de $P$. aculeata aos 37 dias de plantio em substrato alternativo de CAC. Fonte: Autoria própria, 2017.

Estes resultados demostraram que as estacas medianas e basais, em geral, apresentaram melhores resultados de número de brotações por porção. Conforme Fachinello, Hoffmann \& Nachtigal (2005) a composição química varia ao longo do ramo em estacas de diferentes partes de ramos. Dessa forma inferem-se a capacidade de emissão diversa em ramos laterais mesmo que existam variações na mesma estaca de $P$. aculeata. 
Apesar do tempo de análise deste trabalho ter sido curto (37 dias), a observação do perfil das brotações de $P$. aculeata constitui-se um dado novo, uma vez que foi avaliada além do tipo de estaca, a distribuição dos brotos. O conhecimento do perfil de enraizamento também torna-se necessário em estudos futuros, pois esse influencia na viabilidade das plantas.

\section{CONCLUSÃO}

As estacas de $P$. aculeata provenientes de ramos das posições mediana e basal da planta matriz foram as mais viáveis para a propagação vegetativa desta espécie, enquanto as estacas do tipo apical apresentaram maior mortalidade e menor número de brotações;

Quanto à porção, estacas basais destacaram-se no comprimento das brotações nas porções medianas e basais. Em relação ao número médio de brotações, estacas basais e medianas demonstraram melhores resultados e a maior média de brotos foi na porção mediana;

A casca de arroz carbonizada pode ser recomendada como substrato alternativo para a propagação desta espécie, constituindo uma alternativa econômica e om bons resultados.

\section{REFERÊNCIAS}

Accorsi, W. \& Dosouto, R. (2006). Ladainha Comestível. Revista Globo Rural, São Paulo, 244(1), 12.

Aguiar, C. (2014). Arquitetura de Plantas. Instituto Politécnico de Bragança, Escola Superior Agrária, $39 \mathrm{p}$.

Almeida, M. E. F. de, \& Correa, A. D. (2012). Utilização de cactáceas do gênero Pereskia na alimentação humana em um município de Minas Gerais. Ciência Rural, Santa Maria, 42(4), 751-756.

Alvares, C. A., Stape, J. L., Sentelhas, P. C., Gonçalves, J. L. De M., \& Sparovek, G. (2013). Köppen's climate classification map for Brazil. Meteorologische Zeitschrift, 22(6), 711-728.

BRASIL (2006). Lei no 11.346, de 15 de setembro de 2006. Cria o Sistema Nacional de Segurança Alimentar e Nutricional-SISAN com vistas em assegurar o direito humano à alimentação adequada e dá outras providências. Diário Oficial da República Federativa do Brasil, Brasília, DF, 15 set.

BRASIL (2010a). Ministério da Agricultura, Pecuária e Abastecimento. Manual de hortaliças não convencionais. Secretaria de Desenvolvimento Agropecuário e Cooperativismo. Brasília: Mapa/ACS, 62-64.

BRASIL (2010b). Ministério da Agricultura, Pecuária e Abastecimento. Secretaria de Desenvolvimento Agropecuário e Cooperativismo. Hortaliças Não Convencionais (Tradicionais). Brasília: MAPA, $54 \mathrm{p}$.

Carvalho, J. S. B., Nunes, M. F. P. N., Campos, G. P. A., \& Goes, M. C. C. (2015). Influência de diferentes tipos de estacas e substratos na propagação vegetativa de Hyptis pectinata. Revista de Ciências Agroveterinárias, Lages, 14(1), 89-91.

Duarte, M. R., \& Hayashi, S. S. (2005). Estudo anatômico de folha e caule de Pereskia aculeata Mill. (Cactaceae). Revista Brasileira de Farmacognosia. João Pessoa, 15(2),103-109. 
Fachinello, J. C, Hoffmann, A., \& Nachtigal, J. C. (2005). Propagação de plantas frutíferas. Brasília: EMBRAPA. Informação Tecnológica.

Fang, X., Li, Y., Xu, D., Yang, X., \& Wang, G. (2007) Activities of starch hydrolytic enzymes and starch mobilization in roots of Caragana korshinskii following above-ground partial shoot removal. Trees, Heidelberg, 21(1), 93-100.

Farago, P. V. Takeda, I. J. M., Budel, J. M., \& Duarte, M. R. (2004). Análise morfo-anatômica de folhas de Pereskia grandifolia Haw., Cactaceae. Acta Farmaceutica Bonaerense, Buenos Aires, 23(3), 323-327.

Fermino, A. H. (2003). Métodos de análise para caracterização física de substratos para plantas. 2003. 89f., Tese (Doutorado em Fitotecnia). Faculdade de agronomia, Universidade Federal do Rio Grande do Sul. Porto Alegre.

Ferreira, L. E., Andrade, L. A., Gonçalves, G. S., Souza E. P., \& Ferreira H. V. (2010). Diâmetro de estacas e substratos na propagação vegetativa de maniçoba, Manihot glaziovii Muell. Arg. Revista Ciência Agronômica, Fortaleza, 41(3), 393-402. Centro de Ciências Agrárias Universidade Federal do Ceará, Fortaleza, CE.

Floss, E. L. (2004). Fisiologia das plantas cultivadas: o estudo que está por trás do que se vê. Passo Fundo: UPF, 213-223.

Gibson, S.I. (2005). Control of plant development and gene expression by sugar signaling. Current Opinion in Plant Biology, London, 8 (1) 93-102.

Gonçalves, E. G., \& Lorenzi, H. (2007). Morfologia Vegetal: organografia e dicionário ilustrado de morfologia de plantas vasculares. Nova Odessa: Instituto Plantarum, 2007.

Guimarães, H. E. T., Barros, K. N. de, Sartor C.F. P., \& Patroni, S. M. S. (2009). Cultivo e avaliação do teor proteico das folhas de Pereskia aculeata. In: VI EPCC - ENCONTRO INTERNACIONAL DE PRODUÇÃO CIENTÍFICA DO CENTRO UNIVERSITÁRIO DE MARINGÁ, 2009, Maringá. Anais eletrônicos... Maringá: CESUMAR.

Hartmann, H. T., Kester, D. E., Davies Junior, F. T., \& Geneve, R. L. (2002) Plant propagation: principles and practices. 7. ed. New Jersey: Prentice Hall.

Higa, K. M., Fior, C. S., \& Rodrigues, L. (2012). Ensaios para a propagação in vivo e in vitro de orapro-nóbis (Pereskia aculeata). Pequisa Agropecuária Gaúcha, Porto Alegre, 18(1), 59-66.

Kämpf, A. N. (2005). Produção comercial de plantas ornamentais. Guaiba: Agrolivros, 151-156.

Marques, V. B. (2008). Propagação seminífera e vegetativa de pitaia, Hylocereus undatus (Haw.). 85f., Dissertação (Mestrado em Agronomia) - Universidade Federal de Lavras.

Mazia, R. S., \& Sartor, C. F. P. (2012). Influência do tipo de solo usado para o cultivo de Pereskia aculeata sobre propriedade protéica. Revista Saúde e Pesquisa, Maringá, 5(1), 59-65.

Mercê, A. L. R., Landaluze, J. S., Mangrich, A. S., Szpoganicz, B., \& Sierakowski, M. R. (2001). Complexes of arabinogalactan of Pereskia aculeata and $\mathrm{Co}^{2+}, \mathrm{Cu}^{2+}, \mathrm{Mn}^{2+}$ and $\mathrm{Ni}^{2+}$. Bioresource Technology, Essex, v. 76(1), 29-37.

Moran, V.C., \& Zimmermann, H.G. (1991). Biological control of cactos weeds of minor importance in South Africa. Agriculture, Ecosystems and Environmet, Amsterdam, 37(1), 37-55.

Pereira, M. Dos S., Furlan, R.C. M., Furlani Junior E., Sanches C. V., Aguilar J. V., Figueira, L. G. B., \& Penna, L. P. (2015). Desenvolvimento inicial de brotações de pinhão manso em função 
de diferentes tipos de estaca. In: IX WORKSHOP DE AGROENERGIA, 2015, Ribeirão Preto. Anais eletrônicos... Ribeirão Preto: Infobibos, 1: 1-5.

Pinto, N. A. V. D., Vilas Boas, B.M., \& Carvalho, V. D. (1999). Caracterização mineral das folhas de taioba (Xanthosoma sagittifolium Schott). Ciência e Agrotecnologia, Lavras, 23(1), 57-61.

Ramalho, E. Z., \& Mannigel, A. R. (2012) Efeito de doses de adubo orgânico na absorção de nitrogênio por Pereskia aculeata. Anais eletrônico In: VI MOSTRA INTERNA DE TRABALHOS DE INICIAÇÃO CIENTÍFICA DO CENTRO UNIVERSITÁRIO DE MARINGÁ, Maringá. Anais eletrônicos... Maringá: CESUMAR. 1-7.

Raven, P. H., Evert, R. F., \& Eichhorn, S.E. (2007). Biologia Vegetal. 7.ed. Rio de Janeiro: Ed. Guanabara Koogan, 528-529; 565-569; 598-607.

Rocha, D. R. C., Pereira Júnior, G. A., Vieira, G., Pantoja, L., Santos, A. S., \& Pinto, N. A. V. D. (2008) Macarrão adicionado de ora-pro-nóbis (Pereskia aculeata Miller) desidratado. Alimentos e Nutrição, Araraquara, 19(4), 459-465.

Rosa, S. M., \& Souza, L. A. (2003). Morfo-anatomia do fruto (hipanto, pericarpo e semente) em desenvolvimento de Pereskia aculeata Miller (Cactaceae). Acta Scientiarum. Biological Sciences, Maringá, 2(25), 415-428.

Sabará. Festival do Ora-Pro-Nóbis. Disponível em:<http://site.sabara.mg.gov.br/programacao-dofestival-do-ora-pro-nobis/>. Acesso: 03 jul 2017.

SAEG. (2007). Sistema de Análises Estatísticas e Genéticas, Versão 9.1: Fundação Arthur Bernardes - UFV - Viçosa.

Sarno, A. R. R., \& Pasin, L. A. A. P. (2013). Enraizamento de estaca de Pereskia aculeata sob o extrato de Kalanchoe pinnata em diferentes tipos de substratos. In: 13ㅇ CONGRESSO DE INICIAÇÃO CIENTÍFICA DO CONIC-SEMESP DA FACULDADE ANHANGUERA DE CAMPINAS, Campinas. Anais eletrônicos... Campinas: Faculdade Anhanguera.

Sartor, C. P. R., Amaral, V. do, Guimarães, H. E. T., Barros, K. N. De; Felipe, D. F., Cortez, L. E. R., Veltrini, V. C. (2010). Estudo da ação cicatrizante das folhas de Pereskia aculeata. Revista Saúde e Pesquisa, Maringá, 3(2), 149-154.

Silva, C. S. da. (2012) Propagação vegetativa de Pereskia aculeata Mill. (ora-pro-nóbis), utilizando diferentes doses de AIB. In: SALÃO DE INICIAÇÃO CIENTÍFICA, 2012, Porto Alegre. Anais eletrônicos... Porto Alegre: UFRGS.

Silva Júnior, A. A., Nunes, D. G., Bertoldi, F. C., Palhano, M. N., \& Komiekiewicz, N. L. K. (2010). Pão de ora-pro-nóbis: um novo conceito de alimentação funcional. Agropecuária Catarinense, Santa Catarina, v. 23, n. 1, p. 35-37, 2010.

Souza, F. X. (2007) Casca de arroz carbonizada: um substrato para a propagação de plantas. Revista Lavoura Arrozeira, v. 46, n. 406, p.11, 1993 apud CHU E. Y.; DUARTE; M. de L. R.; TREMACOLDI; C. R. Uso da casca de arroz carbonizada como substrato para micorrização de mudas de três cultivares de pimenteira-do-reino. Belém: Embrapa Amazônia Oriental.

Souza, P. V. D. de, Carniel, E., \& Fochesato, M. L. (2006). Efeito da composição do substrato no enraizamento de estacas de maracujazeiro azedo. Revista Brasileira de Fruticultura, Jaboticabal, 28(2), 276-279. 
Souza, M. R. R., Correa, E. J. A., Guimarães, G., \& Pereira, P. R. G. (2009). O potencial do ora-pronóbis na diversificação da produção agrícola familiar. Revista Brasileira de Agroecologia, Porto Alegre, 4(2), 3550-3554.

Taiz, L., \& Zeiger, E. (2006). Fisiologia vegetal. 3.ed. Porto Alegre: Artmed, 376-377; 450-467.

Tavares, I. B., Momnté, V. G., Barreto, H. G., Castro, H. G. de, Santo, G. R. do, Nascimento, I. R. do. (2012). Tipos de estacas e diferentes substratos na propagação vegetativa da erva cidreira (quimiotipos i, ii e iii). Biosci. J., Uberlândia, 28(2), 206-213.

Taylor, N., Santos, M. R., Larocca, J., \& Zappi, D. (2012). Cactaceae. In: Lista de Espécies da Flora do Brasil. Jardim Botânico do Rio de Janeiro.

Tofanelli, M. B. D., \& Resende, S. G. (2011). Sistemas de condução na produção de folhas de orapro-nobis. Pesquisa Agropecuária Tropical, Goiânia, 41(3), 466-469.

Tofanelli, B. D. M., Rodrigues, D. J., \& Ono O. E. (2003). Enraizamento de estacas lenhosas de pessegueiro cv. Okinawa em diferentes diâmetros de ramos, substratos e recipientes. Ciência Rural, Santa Maria, 33(3), 437-442.

Villagra, B. L. P. (2008). Diversidade florística e estrutura da comunidade de plantas trepadeiras no Parque Estadual das Fontes do Ipiranga. 151 f., Dissertação (Mestrado em Biodiversidade Vegetal e Meio Ambiente) - Instituto de Botânica da Secretaria de Estado do Meio Ambiente. 